Supplement of Biogeosciences, 19, 1335-1353, 2022

https://doi.org/10.5194/bg-19-1335-2022-supplement

(C) Author(s) 2022. CC BY 4.0 License.

(c) (1)

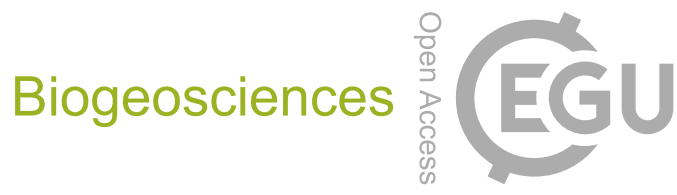

Supplement of

\title{
Physiological and climate controls on foliar mercury uptake by European tree species
}

Lena Wohlgemuth et al.

Correspondence to: Lena Wohlgemuth (lena.wohlgemuth@unibas.ch) and Martin Jiskra (martin.jiskra@unibas.ch)

The copyright of individual parts of the supplement might differ from the article licence. 


\section{Description of tree species groups}

Table S 1. Classification of samples from different tree species within the processed dataset (i.e. after outlier correction) into groups of tree species and respective total number of samples within the processed dataset, including samples from all needle age classes.

\begin{tabular}{|c|c|c|}
\hline Tree species group & Tree species & n samples \\
\hline ash & Fraxinus excelsior & 10 \\
\hline beech & Fagus sylvatica & 372 \\
\hline birch & Betula pendula & 1 \\
\hline Douglas fir & Pseudotsuga menziesii & 55 \\
\hline \multirow{2}{*}{ fir } & Abies alba & 162 \\
\hline & Abies borisii regis & 3 \\
\hline hornbeam & Carpinus betulus & 10 \\
\hline larch & Larix decidua & 3 \\
\hline \multirow{7}{*}{ oak } & Quercus petraea & 133 \\
\hline & Quercus robur & 101 \\
\hline & Quercus (mix: Quercus petraea and Quercus robur) & 42 \\
\hline & Quercus cerris & 4 \\
\hline & Quercus ilex & 4 \\
\hline & Quercus frainetto & 2 \\
\hline & Quercus pubescens & 1 \\
\hline \multirow{6}{*}{ pine } & Pinus sylvestris & 413 \\
\hline & Pinus nigra & 125 \\
\hline & Pinus pinaster & 19 \\
\hline & Pinus cembra & 13 \\
\hline & Pinus mugo arborea & 10 \\
\hline & Pinus nigra subsp. laricio & 3 \\
\hline \multirow{2}{*}{ spruce } & Picea abies & 2073 \\
\hline & Picea sitchensis & 10 \\
\hline
\end{tabular}




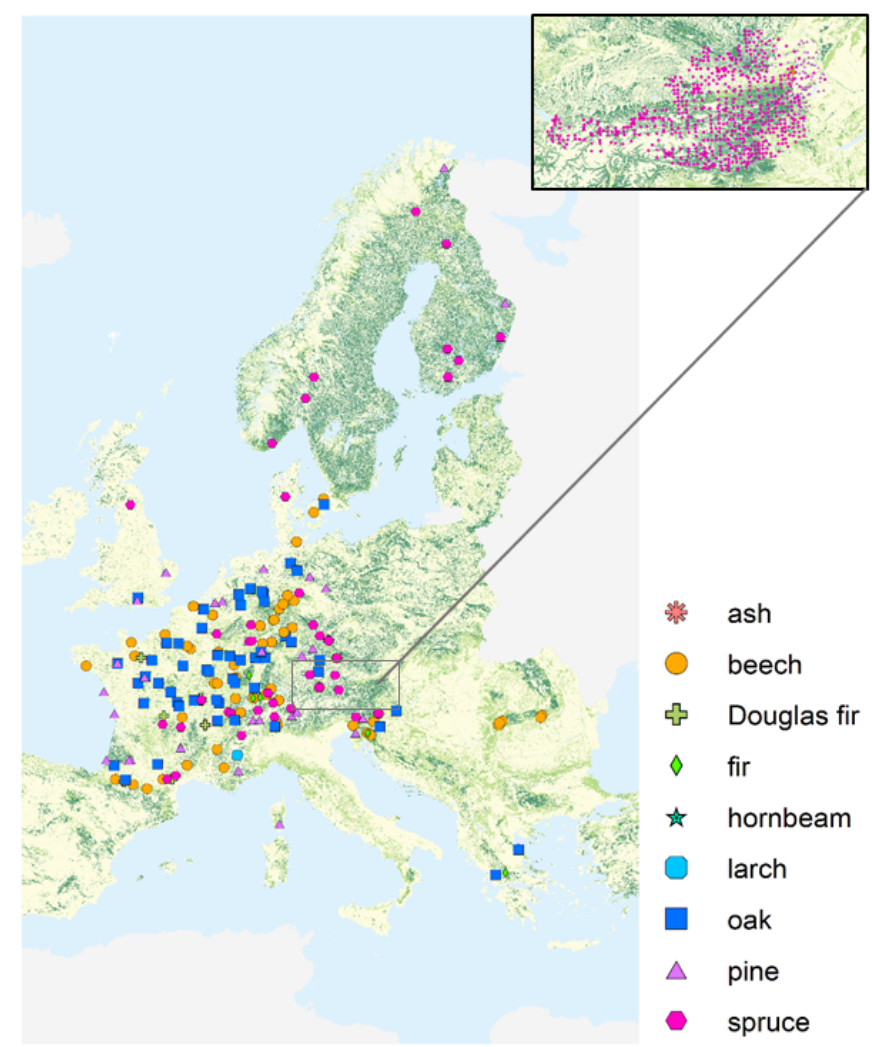

Figure S 1. Overview of forest plots, at which $\mathrm{Hg}$ foliage samples were harvested from different tree species groups during the sampling year 2015. The enlarged map view at the top right depicts sampling locations of the Bio-Indicator Grid in Austria. Use of base map authorized under European Commission reuse policy (EU, 2011). 


\section{Determination of the beginning of the growing season}

\subsection{Matching of observations from the PEP725 database to forest plots}

5 We matched observations on the beginning of the growing season of coniferous trees (flushing of current-season needles) from the Pan European Phenological database PEP725 (Templ et al., 2018) to the corresponding closest forest plot of the respective sampling year (2015 or 2017) within our database. It was necessary to complement start-of-season modelling (Sect. S3.2) with conifer data from an external database, because the utilized PROBA-V LAI modelling method by Bórnez et al. (2020) (see Sect. S3.2) is validated with observations of deciduous tree species (beech, oak, birch, maple) only. Phenological observations of PEP725 sites are classified by BBCH (Biologische Bundesanstalt, Bundessortenamt and chemical industry) phenological scale. We used data for the beginning of the season (needle age class: $\mathrm{y}_{0}$ ) of $\mathrm{BBCH}$ codes 10, 11, 13, 31, 60, 61 and 223. These $\mathrm{BBCH}$ codes correspond to the following growth stages: first leaves separated $(\mathrm{BBCH} 10)$; first true leaf, leaf pair or whorl unfolded, first leaves unfolded (BBCH 11); 3 true leaves, leaf pairs or whorls unfolded (BBCH 13); leaf unfolding (>= $50 \%)(\mathrm{BBCH} 223)$; rosette $10 \%$ of final length (BBCH 31); first flowers open (BBCH 60); beginning of flowering $(\mathrm{BBCH}$ 61). Matching was performed using the nearest neighbor function matchpt from the R Biobase package (Huber et al., 2015) on coordinates of forest plots and PEP725 observation sites. We executed the nearest neighbor matching twice. In the first round, we gave latitude, longitude and altitude as input to the matching function. In a second round, we exclusively matched latitude and altitude of forest plots with a difference between plot and PEP725 observation point larger than three degrees of latitude or $30 \mathrm{~m}$ of altitude (12\% of plots). As a result, spatial distances between forest plots and PEP725 observation points

20 are less than three degrees of latitude and $30 \mathrm{~m}$ of altitude, with an exception of around $6 \%$ of forest plots for which no such close PEP725 observation points were available. A lack of close PEP725 observation points was the case for forest plots in Norway (10 degrees of latitude), Greece (9 degrees of latitude), a few sites in Southern France/Corsica, Southern Switzerland and Austria, and one site in England and Romania respectively (3-6 degrees of latitude). Exceedances of a distance of $30 \mathrm{~m}$ of altitude between forest plots and PEP725 observations emerged for only $1 \%$ of sites with the maximum altitude distance 25 being $350 \mathrm{~m}$. As a result, the average beginning of the season DOY (needle age class: $\mathrm{y}_{0}$ ) for conifers ( $86 \%$ spruce plots, $13 \%$ pine plots, $1 \%$ other conifers) is $127 \pm 14 \mathrm{~d}$ which is one day earlier than the average start-of-season PEP725 observations for spruce from 1970 - 2009 (Basler, 2016).

\subsection{PROBA-V LAI modelling of the beginning of the growing season}

We utilized the leaf area index (LAI) product by Copernicus Global Land Service based on PROBA-V satellite imagery at a resolution of $300 \mathrm{~m}$ and 10 days (Fuster et al., 2020) to model the start of the growing season for deciduous trees as validated by Bórnez et al. (2020). This approach is part of the threshold based methods for growing season modelling (de Beurs and Henebry, 2010). Figure S2 gives an exemplary temporal sequence of PROBA-V LAIs from a forest plot in Switzerland. We defined the start of the growing season as the point in time when the LAI exceeds the $30 \%$ percentile threshold of the amplitude between minimum LAI at the beginning of the growing season and maximum LAI at peak season. Bórnez et al. (2020) found a $30 \%$ percentile amplitude threshold to perform best (root mean squared error of 12.5 days; $\mathrm{R}^{2}=0.62$ ) for PROBA-V LAI modelling when modelling results for the beginning of the growing season were compared to 359 ground phenological observations of deciduous tree species in Europe. In the present ICP Forests database there were three forest plots for which PROBA-V LAI modelling yielded unrealistic results, as the beginning of the growing season was either too early (forest plot Gontrode in 2017) or too late (forest plots Ehrhorn and Maron in 2015) in the season given their respective latitude and altitude. We replaced the beginning of the growing season DOY (day of year) at these three plots with 119 (April 29th) which equals the average beginning of the growing season DOY of deciduous tree species of the present dataset. Figure S3 presents an overview of the modelling results for beginning of the growing season DOYs at each deciduous forest plot per latitude. The coefficient of correlation of linear regression between beginning of growing season DOYs and latitude was positive and significant $(\mathrm{p}<0.01)$, so as a tendency, the beginning of the growing season DOYs modelled here correspond to expected latitudinal differences. The average beginning of the growing season DOY (mean \pm s.d. in days) is $120 \pm 10 \mathrm{~d}$ for beech and $111 \pm 11 \mathrm{~d}$ for oak. This average beginning of the growing season DOY for beech is consistent within an accuracy of 2 days with 7840 PEP725 observations from Central Europe between the years 1970 - 2009 (Basler, 2016). For oak, the modelled 
beginning of the growing season is 13 days earlier than the respective average DOY from 6400 PEP725 observations between 1970 - 2009 (Basler, 2016). This 13 d discrepancy could be due to the fact that the PEP725 oak beginning of season data evaluated by Basler (2016) comprise observations mainly from Germany, while $26 \%$ of oak samples in the current data set originated from more southern latitudes $<48^{\circ}$.

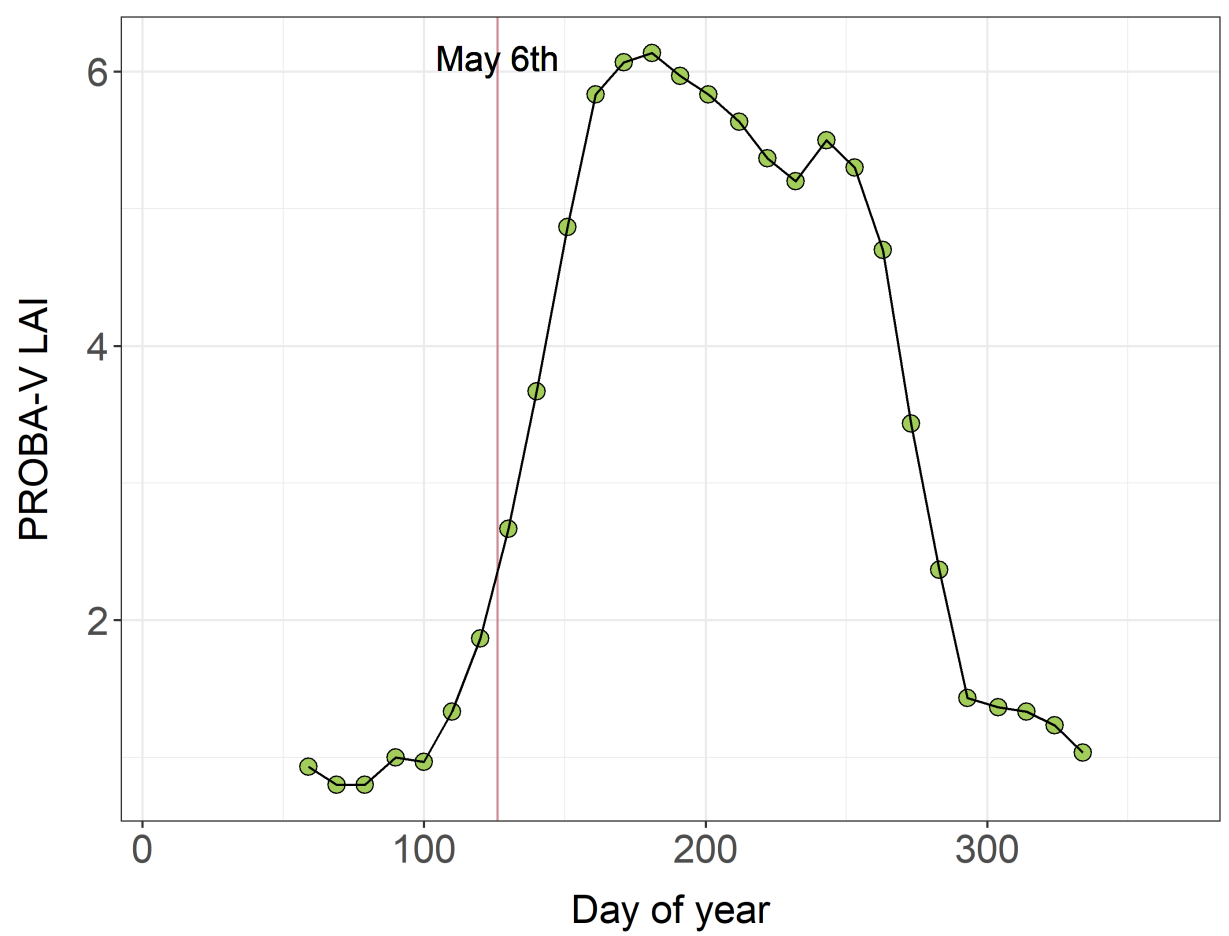

Figure S 2. Temporal development of the Copernicus LAI (leaf area index) values derived from PROBA-V satellite images (Fuster et al., 2020) at the Swiss forest research site Bettlachstock in 2017. The beginning of the growing season is defined as the date, at which the LAI value exceeds the 30 percentile threshold of the amplitude between minimum LAI early in the year and maximum LAI at peak season following a modelling approach by Bórnez et al. (2020). Here the beginning of the growing season corresponds to May 6th 2017. This date is one week later than the average beginning of the growing season of this dataset for beech, which represents the main tree species at Bettlachstock. Given that Bettlachstock is located at $1101 \mathrm{~m}-1196 \mathrm{~m}$ above sea level, however, May 6th is a plausible beginning of the growing season for beech at this site. 


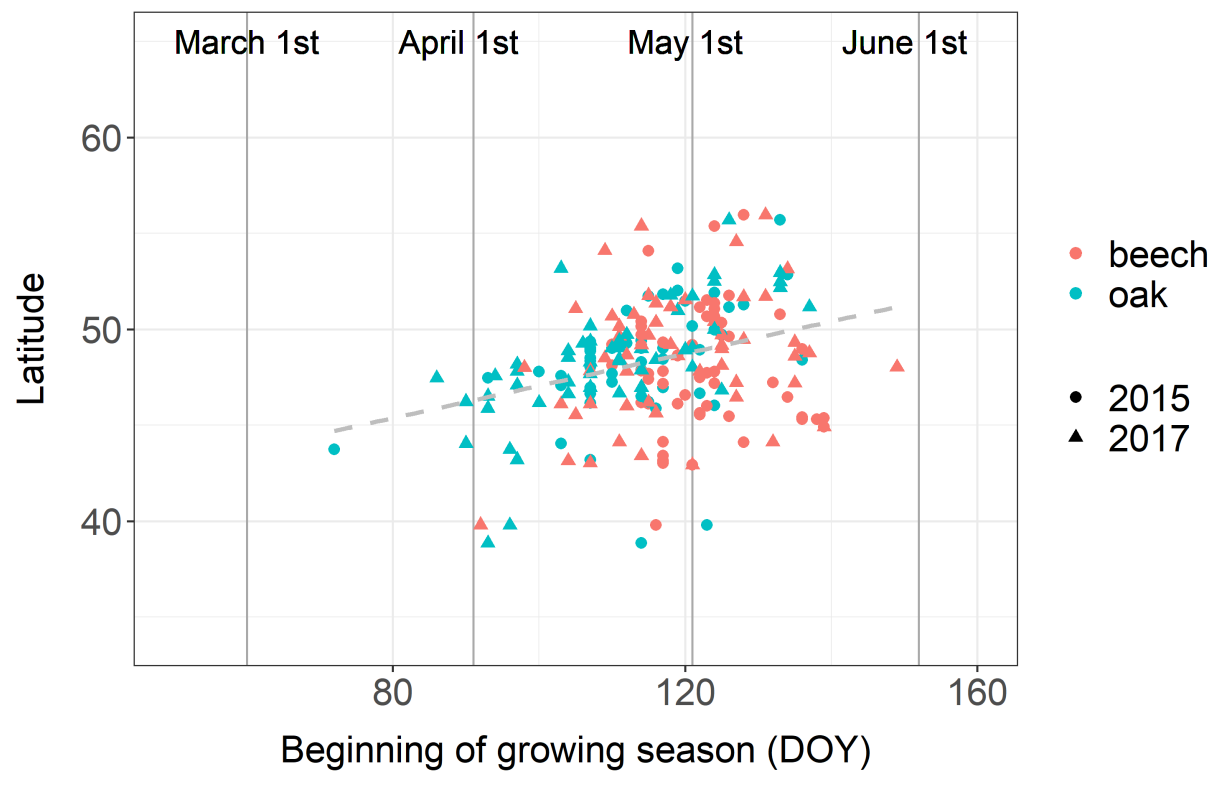

Figure S 3. Start-of-season DOY (day of year) at ICP Forests Level II plots resulting from growing season modelling approach after Bórnez et al. (2020) 


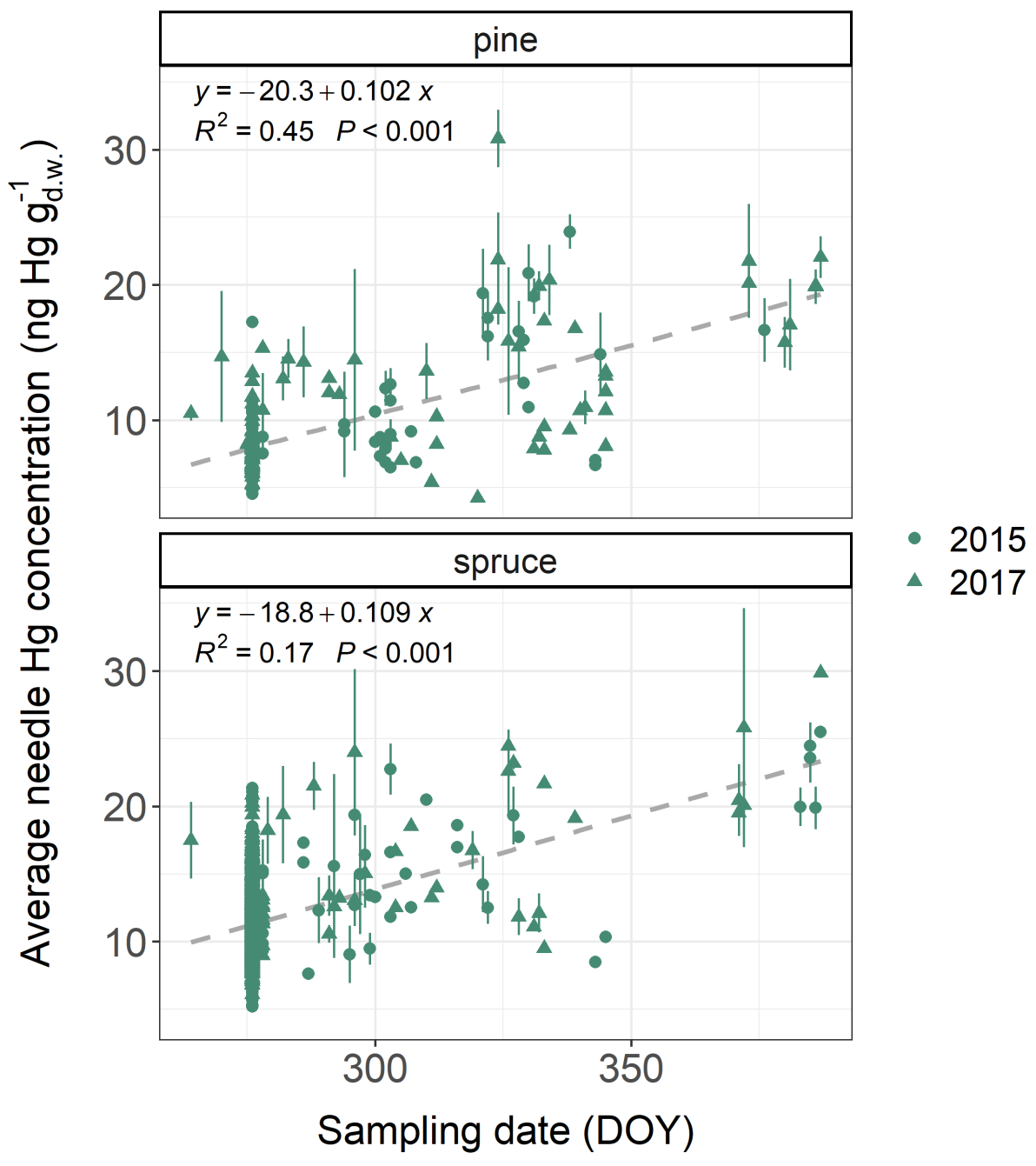

Figure S 4. Average foliar $\mathrm{Hg}$ concentrations ( $\mathrm{ng} \mathrm{Hg} \mathrm{g}_{d . w}^{-1}$.) per forest plot of pine and spruce samples versus respective sampling date (day-of-year of both 2015 and 2017). At some pine and spruce forest plots sampling took place in winter after 31st of December, such that day-of-year $>365$. Error bars denote \pm one standard deviation between multiple foliage samples at one forest plot. All samples represent current-season values. 


\section{Foliar Hg uptake per tree species}

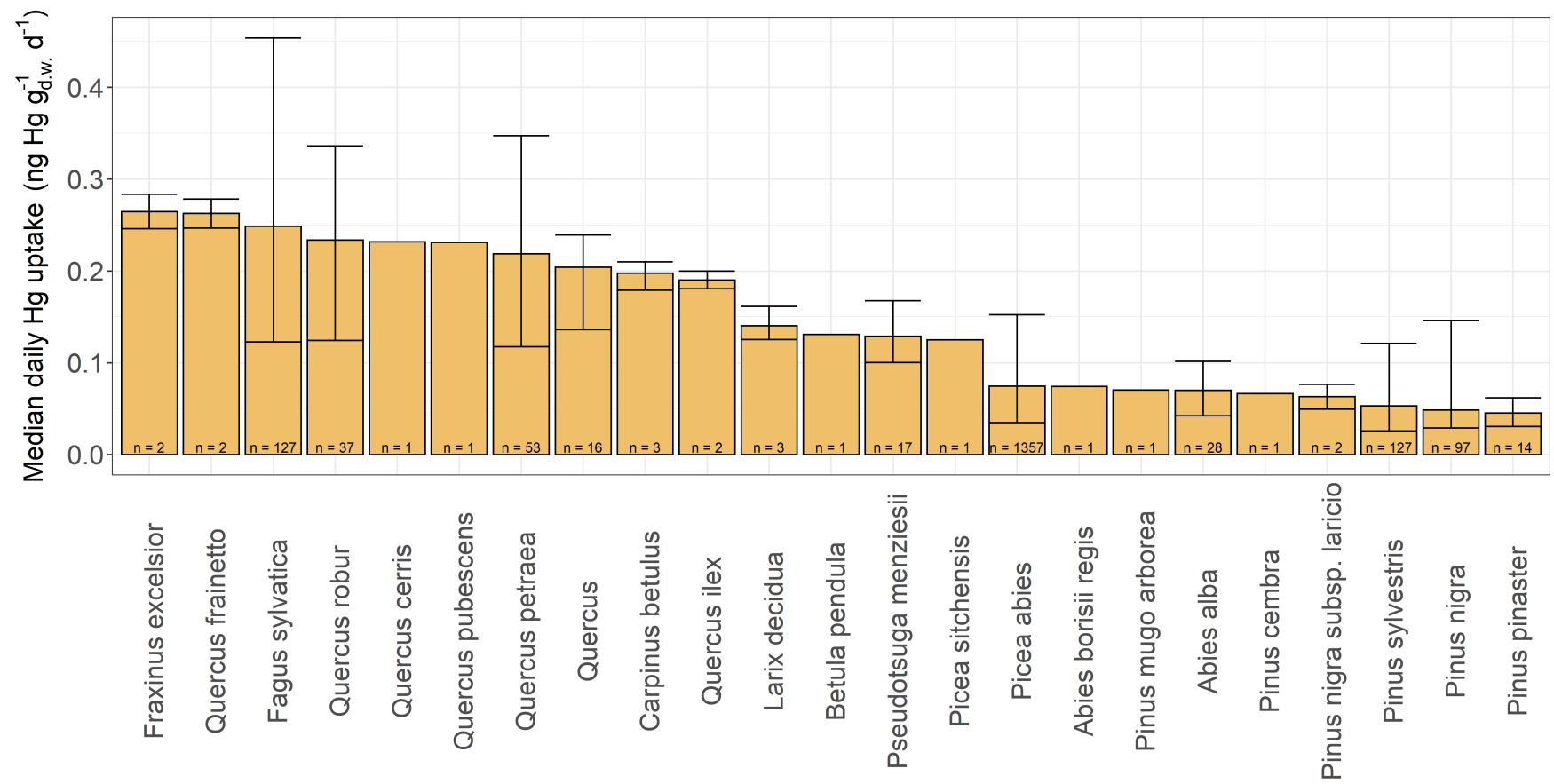

Figure S 5. Median daily foliar $\mathrm{Hg}$ uptake ( $\operatorname{ng~} \mathrm{Hg} \mathrm{g}_{d . w}^{-1} \mathrm{~d}^{-1}$ ) of different tree species arranged from highest to lowest value. Error bars give the value range within each tree species and $n$ indicates the number of sites at which the respective tree species were sampled in sum in the years 2015 and 2017. Foliar samples of evergreen coniferous tree species consist of needles of the current season. Quercus represents a mix of samples from Quercus petraea and Quercus robur.

\section{Atmospheric $\mathrm{Hg}(0)$ concentrations from EMEP stations}

55 In order to get a better understanding of the variation in atmospheric $\mathrm{Hg}(0)$ in Europe during the growing seasons 2015 and 2017, we obtained air Hg data from the European Monitoring and Evaluation Programme (EMEP) (Tørseth et al., 2012; EMEP, 2016). Air Hg measurements for 2015 and 2017 were available at 6 stations (Table S2, Fig. S6). Measurements from one station (Iskrba) between May - Sept. 2015 were excluded from the dataset due to abnormally low air $\mathrm{Hg}$ values $\left(0.41 \pm 0.13 \mathrm{ng} \mathrm{m}^{-3}\right.$; mean \pm sd). Selection of stations was based on availability of measurements in Europe at the relevant time intervals. The temporal frequency of measurements (hourly to 6 days) and consequently the number of measurements varied between the different EMEP stations (Table S2). 
Table S 2. Details on air Hg measurements at 6 EMEP stations during the growing seasons 2015 and 2017.

\begin{tabular}{l|ccccccc}
\hline \multirow{2}{*}{ Station name } & EMEP code & $\begin{array}{c}\text { coordinates } \\
\text { (lat, lon) }\end{array}$ & $\begin{array}{c}\text { altitude } \\
(\mathrm{m})\end{array}$ & frequency & time coverage & $\begin{array}{c}\text { air Hg (mean } \pm \text { sd) } \\
\left(\mathrm{ng} \mathrm{m}^{-3}\right)\end{array}$ & $\mathrm{n}$ \\
\hline Andøya & NO0090R & $69.28,16.01$ & 380 & hourly & May - Sept. 2015 & $1.50 \pm 0.09$ & 3371 \\
\hline Auchencorth Moss & GB0048R & $55.79,-3.24$ & 260 & 3hourly & May - Sept. 2015 & $1.33 \pm 0.15$ & 1384 \\
& & & & hourly & May - Sept. 2017 & $1.40 \pm 0.12$ & 2285 \\
\hline BirkenesII & NO0002R & $58.39,8.25$ & 219 & hourly & May - Sept. 2015 & $1.49 \pm 0.24$ & 3402 \\
\hline Diabla Gora & PL0005R & $54.15,22.07$ & 157 & 6 days & May - Sept. 2015 & $1.26 \pm 0.45$ & 23 \\
\hline Iskrba & SI0008R & $45.57,14.87$ & 520 & daily & May - Sept. 2017 & $1.33 \pm 0.80$ & 39 \\
\hline Laheema & EE0009R & $59.5,25.9$ & 32 & hourly & May - July 2015 & $1.40 \pm 0.38$ & 1396
\end{tabular}

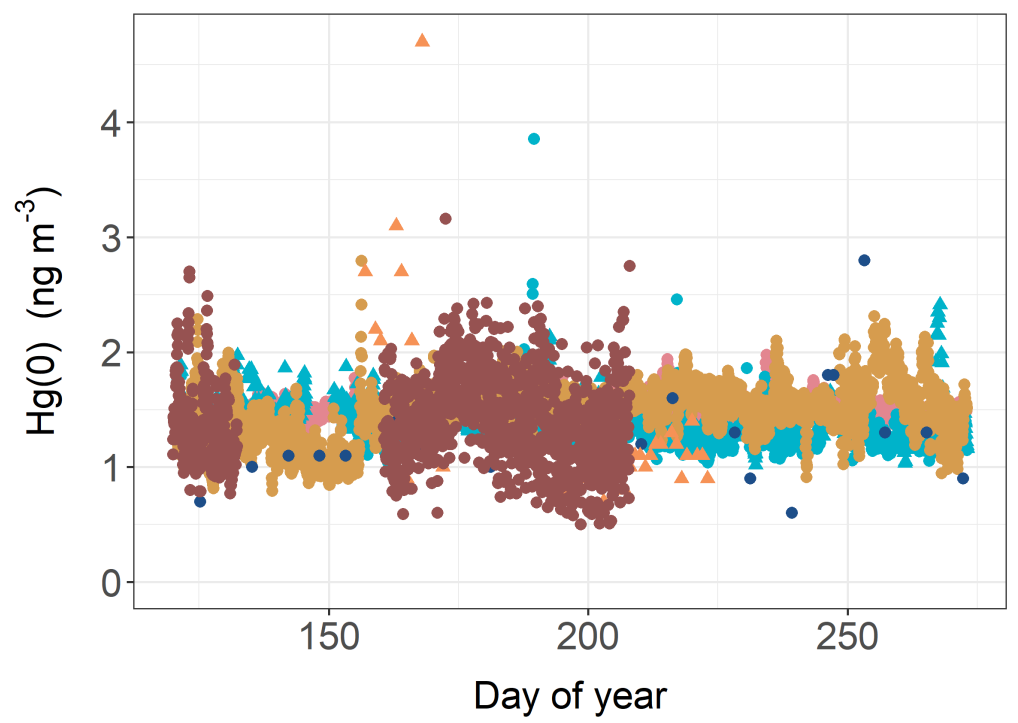

Site (Latitude, Longitude)

- Andøya $(69.28,16.01)$

- Auchencorth Moss (55.79, -3.24)

- BirkenesIl $(58.89,8.25)$

- Diabla Gora $(54.15,22.07)$

- Iskrba $(45.57,14.87)$

- Lahemaa $(59.5,25.9)$

\section{Year}

- 2015

- 2017

Figure S 6. Temporal resolution of air $\mathrm{Hg}$ at 6 EMEP stations during the growing seasons 2015 and 2017. For details on EMEP stations see Table S2. 
7 Calculation of median leaf stomatal conductance from data by Lin et al. (2015)

We calculated median stomatal conductance values from a global database of leaf-level gas exchange parameters compiled by 65 Lin et al. (2015) from literature and unpublished sources. We exported stomatal conductance values of the following tree species from the database: beech (Fagus sylvatica), oak (Quercus petraea, Quercus robur), spruce (Picea abies) and pine (Pinus edulis, Pinus pinaster, Pinus sylvestris, Pinus taeda). All data were measured in Europe (Denmark, Finland, France, Germany, Sweden, UK) and North America. The following data contributors were named as data source for the data we used to calculate median stomatal conductance per tree species: Alexandre Bosc, D. Ellsworth, Jean-Marc Limousin, John Drake, Lasse Tarvainen, Maj-

70 Lena Linderson, Mark Broadmeadow, Michael Freeman, Pasi Kolari, Reinhart Ceulemans and Mark Low. The database can be accessed at https://figshare.com/articles/dataset/Optimal_stomatal_behaviour_around_the_world/1304289. 


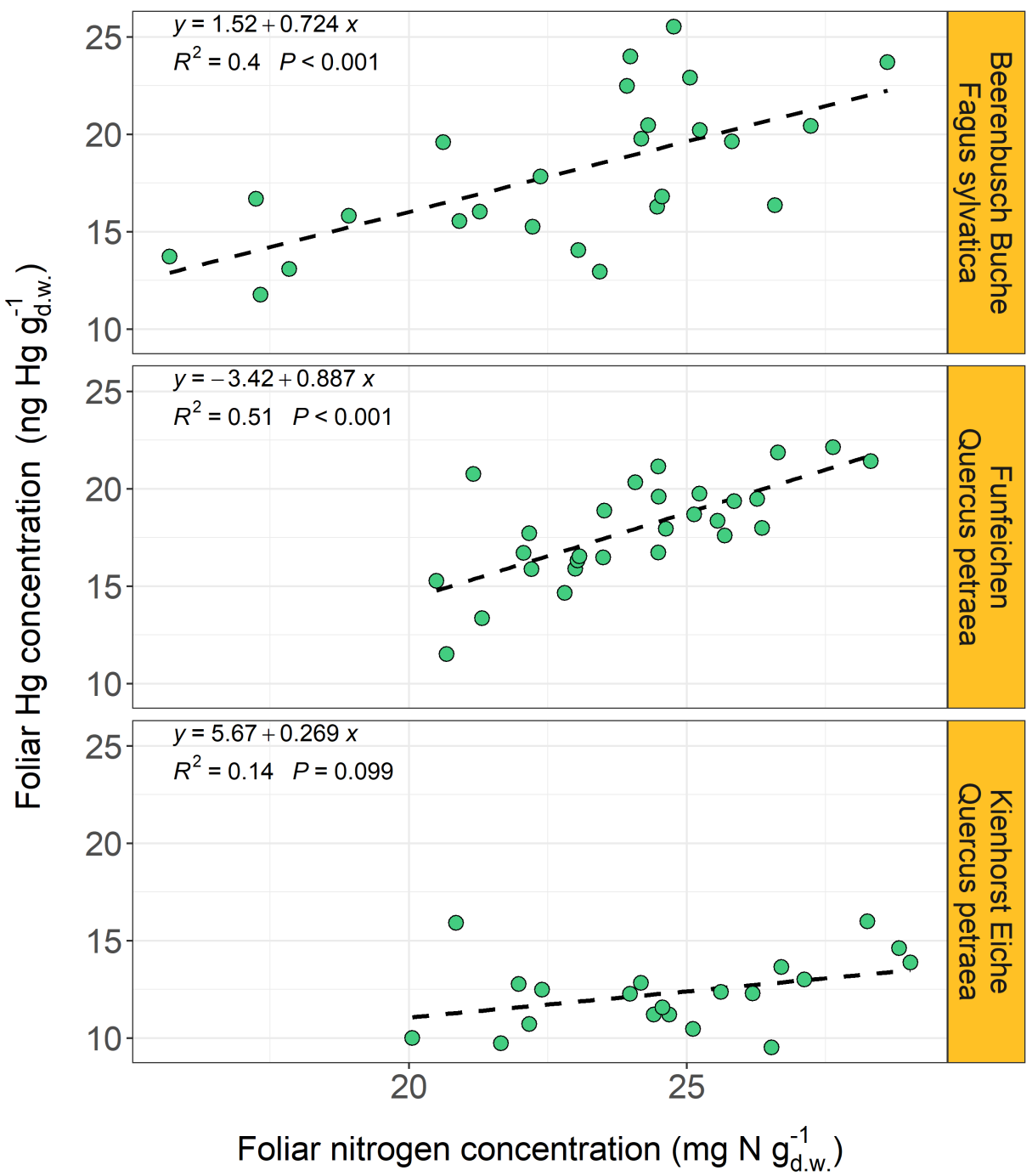

Figure S 7. Linear regression between foliar $\mathrm{Hg}$ concentrations $\left(\mathrm{ng} \mathrm{Hg} \mathrm{g}_{d . w}^{-1}\right.$ ) and leaf nitrogen concentration $\left(\mathrm{mg} \mathrm{N}_{d . w}^{-1}\right)$ in foliage samples from one beech (Fagus sylvatica, top) and two oak (Quercus petraea) forest plots in Brandenburg, Germany. 


\section{Foliar Hg uptake and Leaf Mass per Area}

Table S 3. Daily Hg uptake rates, foliar N concentrations and leaf mass per area (LMA) values (mean \pm sd) presented in Figure 4.

\begin{tabular}{l|cccr}
\hline \multirow{2}{*}{ Species group } & $\begin{array}{c}\text { daily } \mathrm{Hg} \text { uptake } \\
\left(\mathrm{ng} \mathrm{Hg} \mathrm{g}_{d . w .}^{-1}\right) \\
(\text { mean } \pm \mathrm{sd})\end{array}$ & $\begin{array}{c}\text { foliar } \mathrm{N} \text { conc. } \\
\left(\mathrm{mg} \mathrm{N} \mathrm{g}_{\text {d.w. }}^{-1}\right)\end{array}$ & $\begin{array}{c}\text { LMA } \\
\left(\mathrm{g}_{\text {d.w. }} \mathrm{m}_{\text {leaf }}^{-2}\right)\end{array}$ & $\mathrm{n}$ \\
$(\mathrm{mean})$ & $($ mean $)$ & \\
\hline beech & $0.26 \pm 0.05$ & $23.0 \pm 2.8$ & $68 \pm 16$ & 164 \\
hornbeam & $0.19 \pm 0.04$ & $18.9 \pm 1.4$ & $67 \pm 11$ & 9 \\
pine & $0.10 \pm 0.02$ & $16.1 \pm 2.1$ & $243 \pm 84$ & 35 \\
Douglas fir & $0.12 \pm 6 \mathrm{e}-5$ & $19.0 \pm 2.2$ & $284 \pm 5$ & 2 \\
oak & $0.22 \pm 0.05$ & $24.7 \pm 2.7$ & $100 \pm 17$ & 106 \\
spruce & $0.11 \pm 0.02$ & $14.5 \pm 1.0$ & $370 \pm 67$ & 33
\end{tabular}
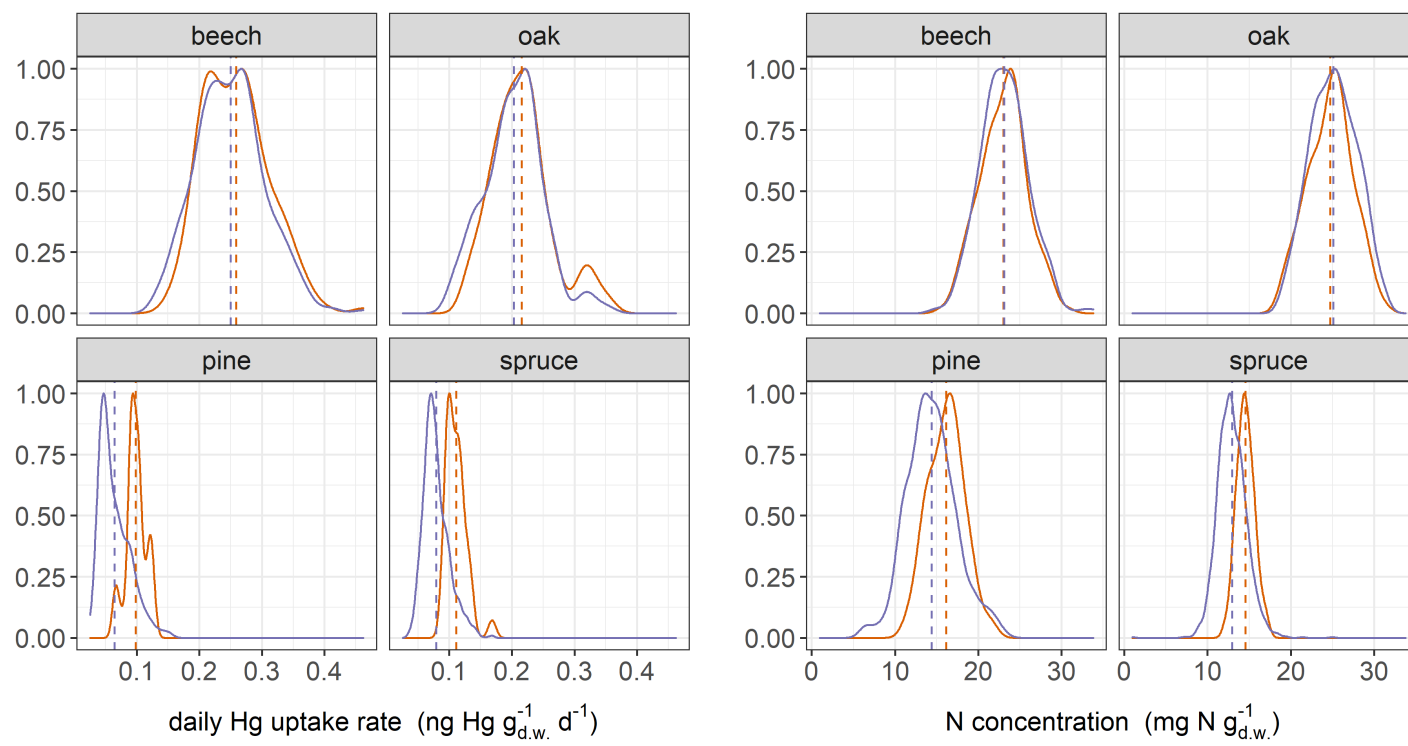

Figure S 8. Density (scaled to respective maximum value) within the datasets of daily $\mathrm{Hg}$ uptake rates (left) and foliar $\mathrm{N}$ concentrations (right) of beech leaves, oak leaves, current-season pine needles and current-season spruce needles presented in Table 2 and in Figure 4 . Data from Figure 4 is a sub-dataset of the dataset from Table 2. The shift in daily needle $\mathrm{Hg}$ uptake rates of pine and spruce between the two datasets is possibly associated with a shift in needle $\mathrm{N}$ concentrations between the two datasets. 

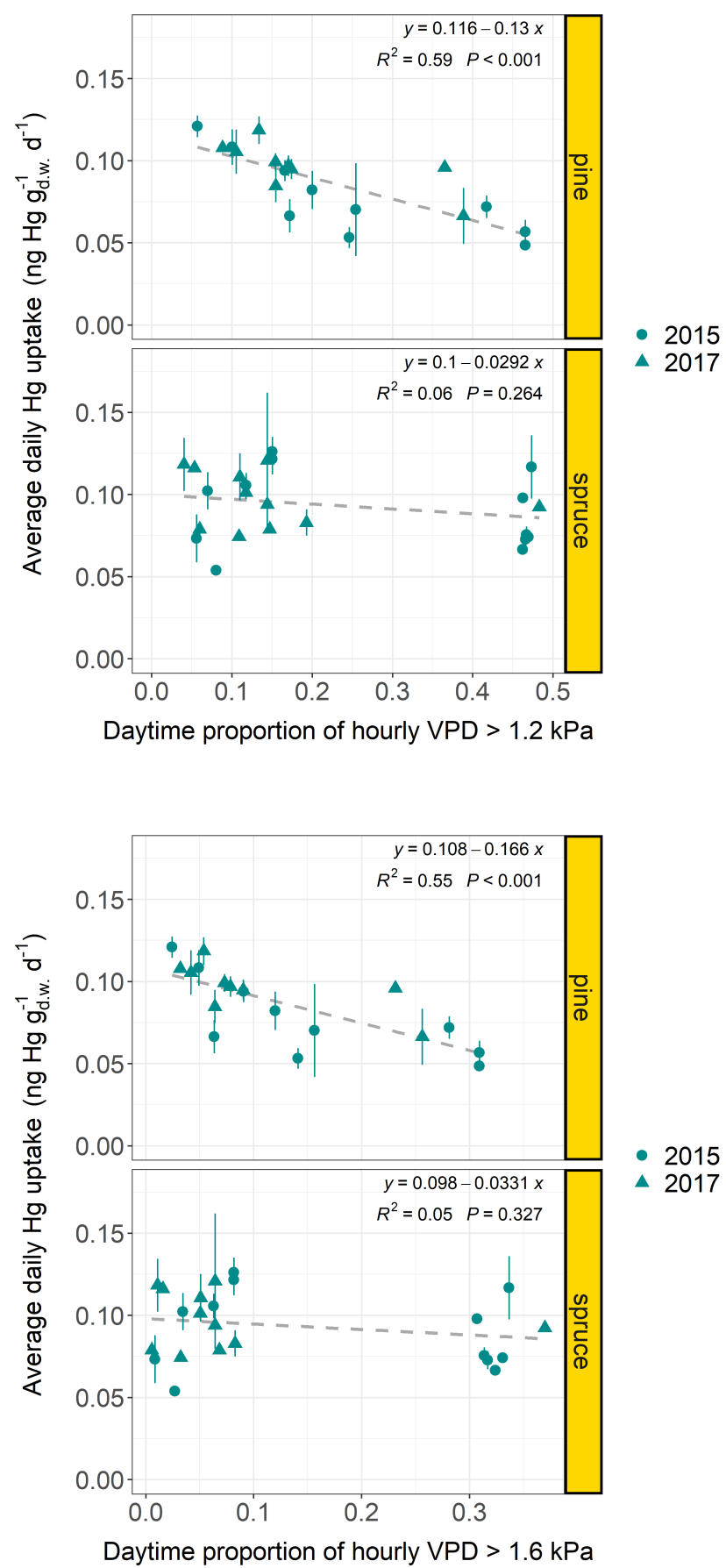


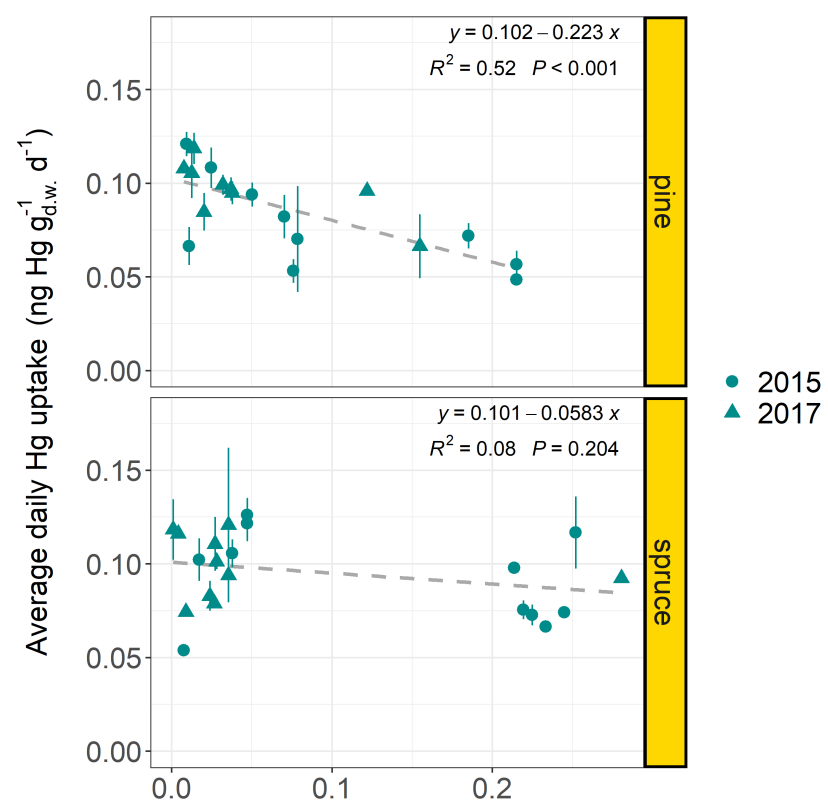

Daytime proportion of hourly VPD $>2 \mathrm{kPa}$

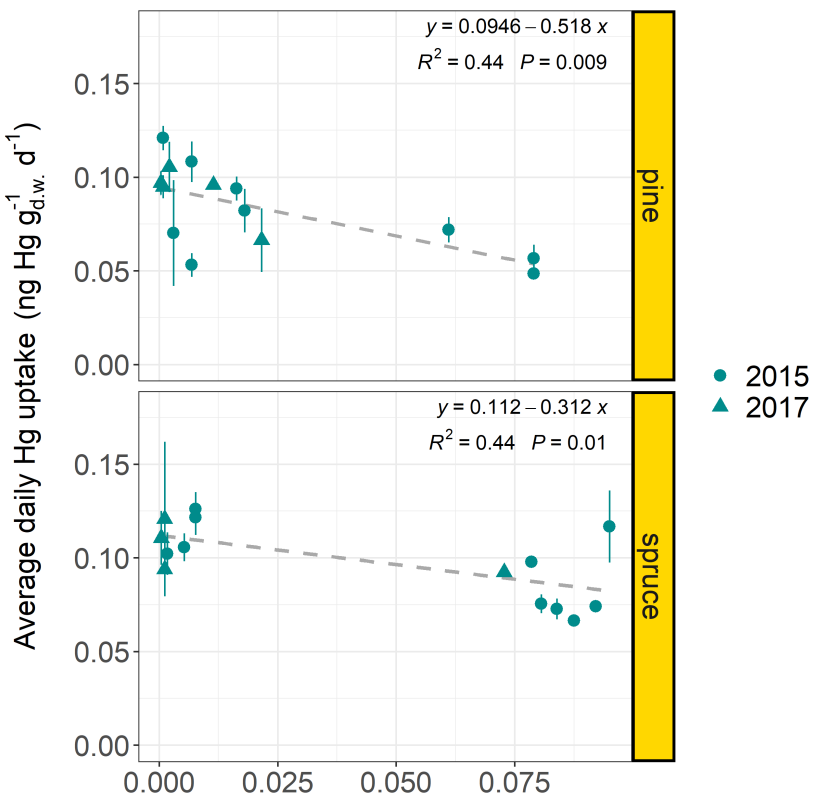

Daytime proportion of hourly VPD $>3 \mathrm{kPa}$

Figure S 9. Average daily foliar $\mathrm{Hg}$ uptake rates $\left(\mathrm{ng} \mathrm{Hg} \mathrm{g}_{d . w}^{-1} \mathrm{~d}^{-1}\right)$ of current-season pine and spruce needles per forest plot sampled in 2015 and 2017 versus the proportion of hours within an average day of the respective sample life periods, during which the average hourly daytime (06:00 - 18:00 LT) vapor pressure deficit (VPD) exceeded a threshold value of $1.2 \mathrm{kPa}, 1.6 \mathrm{kPa}, 2 \mathrm{kPa}$ and $3 \mathrm{kPa}$ respectively. Error bars denote \pm one standard deviation between multiple samples at each forest plot. 

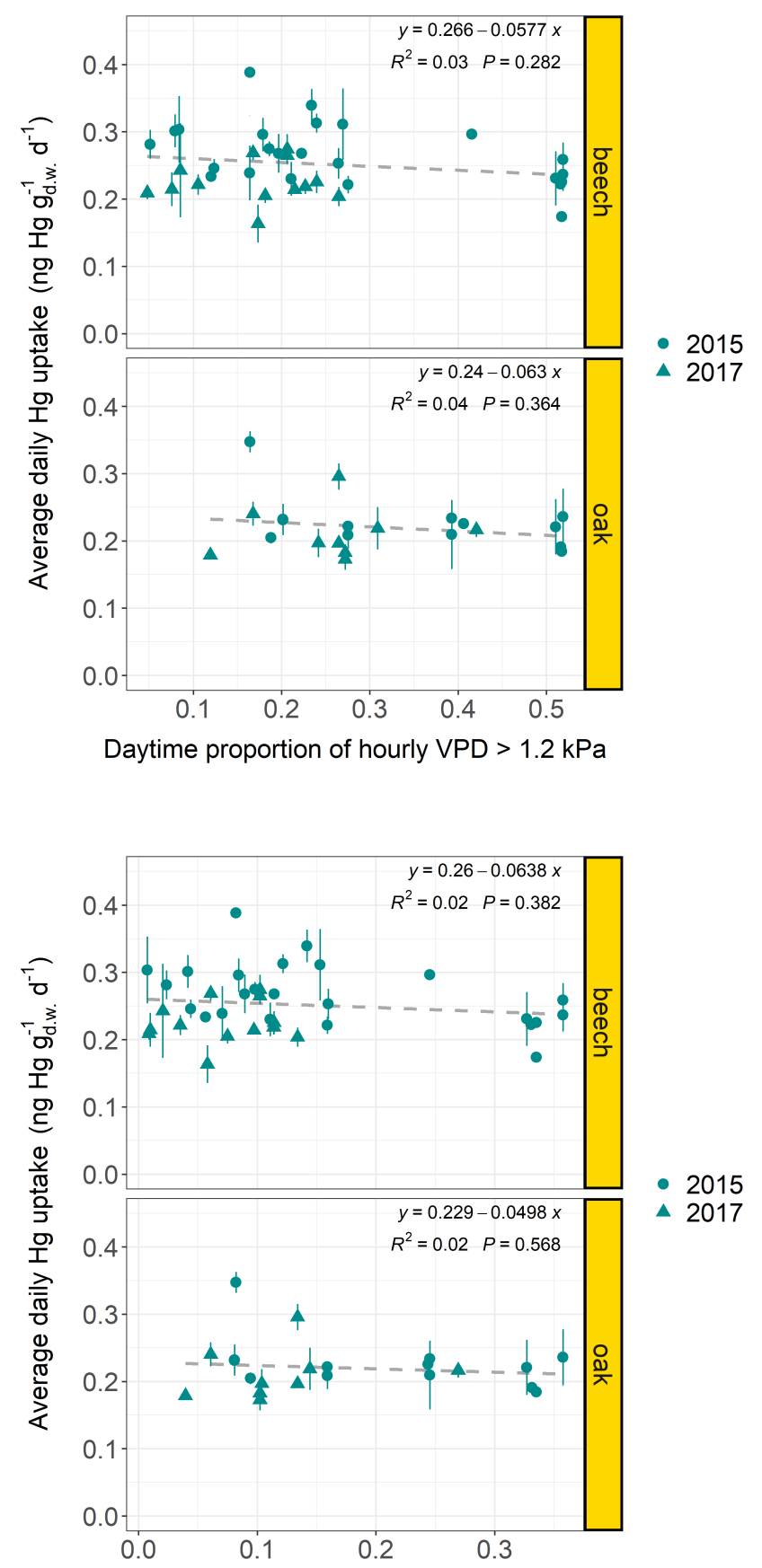

Daytime proportion of hourly VPD $>1.6 \mathrm{kPa}$ 

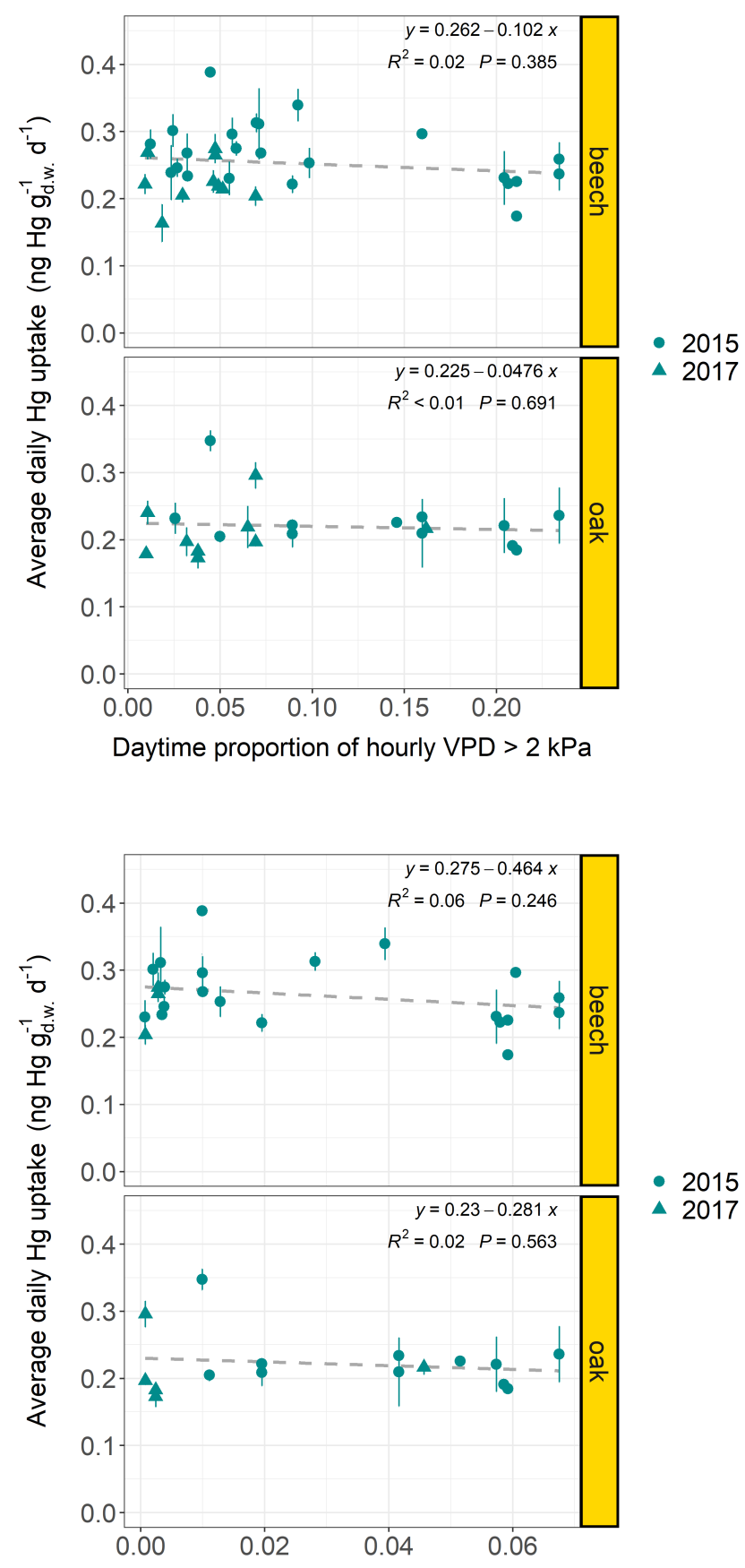

Daytime proportion of hourly VPD $>3 \mathrm{kPa}$

Figure S 10. Average daily foliar $\mathrm{Hg}$ uptake rates $\left(\mathrm{ng} \mathrm{Hg} \mathrm{g}_{d . w}^{-1}, \mathrm{~d}^{-1}\right.$ ) of beech and oak leaves per forest plot sampled in 2015 and 2017 versus the proportion of hours within an average day of the respective sample life periods, during which the average hourly daytime (06:00 - 18:00 LT) vapor pressure deficit (VPD) exceeded a threshold value of $1.2 \mathrm{kPa}, 1.6 \mathrm{kPa}, 2 \mathrm{kPa}$ and $3 \mathrm{kPa}$ respectively. Error bars denote \pm one standard deviation between multiple samples at each forest plot. 
Table S 4. Soil texture specific soil water at field capacity $\left(\mathrm{SW}_{F C}\right)$ and at the permanent wilting point $\left(\mathrm{SW}_{P W P}\right)$, plant available water

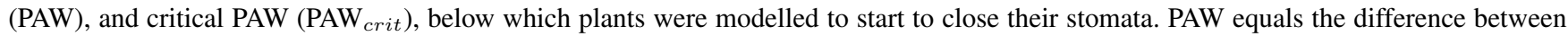
$\mathrm{SW}_{F C}$ and $\mathrm{SW}_{P W P}$ and $\mathrm{PAW}$ crit $=0.5 \cdot \mathrm{PAW}+\mathrm{SW}_{P W P}$. All values are taken from Saxton and Rawls (2006) (Table 3) and represent units of $\mathbf{m}^{3} \mathbf{m}^{-3}$.

\begin{tabular}{l|cccc}
\hline Soil texture & $\mathbf{S W}_{F C}$ & $\mathbf{S W}_{P W P}$ & PAW & PAW $_{\text {crit }}$ \\
\hline Sand & 0.10 & 0.05 & 0.05 & 0.075 \\
Loamy sand & 0.12 & 0.05 & 0.07 & 0.085 \\
Sandy loam & 0.18 & 0.08 & 0.10 & 0.13 \\
Sandy clay loam & 0.27 & 0.17 & 0.10 & 0.22 \\
Clay & 0.42 & 0.30 & 0.12 & 0.36 \\
Silty clay & 0.41 & 0.27 & 0.14 & 0.34 \\
Clay loam & 0.36 & 0.22 & 0.14 & 0.29 \\
Loam & 0.28 & 0.14 & 0.14 & 0.21 \\
Silty clay loam & 0.38 & 0.22 & 0.16 & 0.30 \\
Silt loam & 0.31 & 0.11 & 0.20 & 0.21
\end{tabular}


Location: Mazamet (France)

Soil texture at forest plot between 0 and $10 \mathrm{~cm}$ : Sandy clay loam

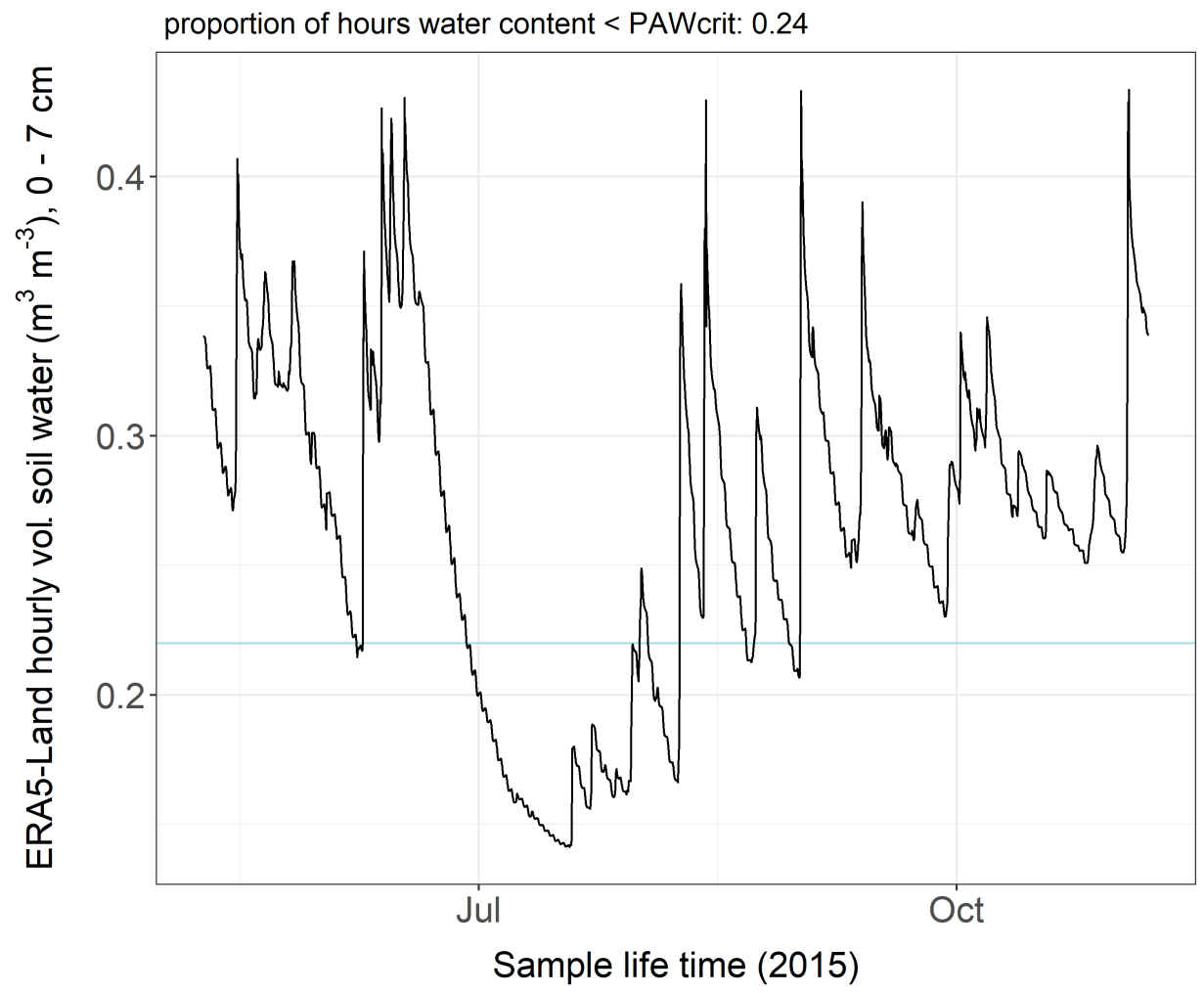

Figure S 11. Volumetric soil water $\left(\mathrm{m}^{3} \mathrm{~m}^{-3}\right.$, layer 1) from the ERA5-Land hourly dataset (Muñoz Sabater, 2019) in the region of Mazamet (France) versus sample life period of the associated ICP Forests Level II Plot (plot code: 1-45). The lightblue line denotes the threshold value of plant available water ( $\mathrm{PAW}_{\text {crit }}$ ) of $0.22 \mathrm{~m}^{3} \mathrm{~m}^{-3}$ for the soil texture (sandy clay loam) of this forest plot (compare Table 4, this document). 


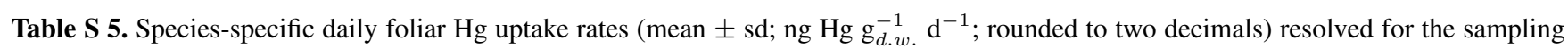
years 2015 and 2017 and difference between respective average daily foliar $\mathrm{Hg}$ uptake rates of 2015 - average daily foliar Hg uptake rates of 2017.

\begin{tabular}{|c|c|c|c|c|}
\hline Tree species group & sampling year & $\begin{array}{l}\text { Daily } \mathrm{Hg} \text { uptake }(\text { mean } \pm \mathrm{sd}) \\
\quad\left(\mathrm{ng} \mathrm{Hg} \mathrm{g}_{d . w .}^{-1} \mathrm{~d}^{-1}\right)\end{array}$ & $\begin{array}{l}\text { Diff. daily Hg uptake } \\
\qquad(2015 \text { - 2017) }\end{array}$ & $\mathrm{n}$ sites \\
\hline \multirow{2}{*}{ beech } & 2015 & $0.27 \pm 0.05$ & \multirow{2}{*}{0.04} & \multirow{2}{*}{51} \\
\hline & 2017 & $0.23 \pm 0.04$ & & \\
\hline \multirow{2}{*}{ Douglas fir } & 2015 & $0.12 \pm 0.02$ & \multirow{2}{*}{-0.02} & \multirow{2}{*}{7} \\
\hline & 2017 & $0.14 \pm 0.02$ & & \\
\hline \multirow{2}{*}{ fir } & 2015 & $0.07 \pm 0.02$ & \multirow{2}{*}{-0.005} & \multirow{2}{*}{6} \\
\hline & 2017 & $0.08 \pm 0.02$ & & \\
\hline \multirow{2}{*}{ oak } & 2015 & $0.23 \pm 0.04$ & \multirow{2}{*}{0.004} & \multirow{2}{*}{49} \\
\hline & 2017 & $0.22 \pm 0.03$ & & \\
\hline \multirow{2}{*}{ pine } & 2015 & $0.05 \pm 0.02$ & \multirow{2}{*}{$\sim 0$} & \multirow{2}{*}{107} \\
\hline & 2017 & $0.05 \pm 0.02$ & & \\
\hline \multirow{2}{*}{ spruce } & 2015 & $0.07 \pm 0.02$ & \multirow{2}{*}{-0.003} & \multirow{2}{*}{658} \\
\hline & 2017 & $0.08 \pm 0.02$ & & \\
\hline
\end{tabular}




\section{References}

Basler, D.: Evaluating phenological models for the prediction of leaf-out dates in six temperate tree species across central Europe, Agr. Forest Meteorol., 217, 10-21, https://doi.org/10.1016/j.agrformet.2015.11.007, 2016.

Bórnez, K., Descals, A., Verger, A., and Peñuelas, J.: Land surface phenology from VEGETATION and PROBA-V data. Assessment over deciduous forests, Int. J. Appl. Earth Obs., 84, 101 974, https://doi.org/10.1016/j.jag.2019.101974, 2020.

de Beurs, K. M. and Henebry, G. M.: Spatio-temporal statistical methods for modelling land surface phenology, in: Phenological research: Methods for environmental and climate change analysis, Springer Netherlands, pp. 177-208, https://doi.org/10.1007/978-90-481-33352_9,2010.

EMEP: Air pollution trends in the EMEP region between 1990 and 2012, Joint Report, https://unece.org/environment-policy/publications/ air-pollution-trends-emep-region-between-1990-and-2012, 2016.

EU: European Commission, 2011/833/EU: Commission decision of 12 December 2011 on the reuse of Commission documents, https: //eur-lex.europa.eu/eli/dec/2011/833/oj, 2011.

Fuster, B., Sánchez-Zapero, J., Camacho, F., García-Santos, V., Verger, A., Lacaze, R., Weiss, M., Baret, F., and Smets, B.: Quality assessment of PROBA-V LAI, fAPAR and fCOVER collection 300 m products of Copernicus Global Land Service, Remote Sens., 12, 1017, https://doi.org/10.3390/rs12061017, 2020.

Huber, W., Carey, V. J., Gentleman, R., Anders, S., Carlson, M., Carvalho, B. S., Bravo, H. C., Davis, S., Gatto, L., Girke, T., Gottardo, R., Hahne, F., Hansen, K. D., Irizarry, R. A., Lawrence, M., Love, M. I., MacDonald, J., Obenchain, V., Oleś, A. K., Pagès, H., Reyes, A., Shannon, P., Smyth, G. K., Tenenbaum, D., Waldron, L., and Morgan, M.: Orchestrating high-throughput genomic analysis with Bioconductor, Nat. Methods, 12, 115-121, https://doi.org/10.1038/nmeth.3252, 2015.

Lin, Y.-S., Medlyn, B. E., Duursma, R. A., Prentice, I. C., Wang, H., Baig, S., Eamus, D., de Dios, V. R., Mitchell, P., Ellsworth, D. S., de Beeck, M. O., Wallin, G., Uddling, J., Tarvainen, L., Linderson, M.-L., Cernusak, L. A., Nippert, J. B., Ocheltree, T. W., Tissue, D. T., Martin-StPaul, N. K., Rogers, A., Warren, J. M., De Angelis, P., Hikosaka, K., Han, Q., Onoda, Y., Gimeno, T. E., Barton, C. V. M., Bennie, J., Bonal, D., Bosc, A., Löw, M., Macinins-Ng, C., Rey, A., Rowland, L., Setterfield, S. A., Tausz-Posch, S., Zaragoza-Castells, J., Broadmeadow, M. S. J., Drake, J. E., Freeman, M., Ghannoum, O., Hutley, L. B., Kelly, J. W., Kikuzawa, K., Kolari, P., Koyama, K., Limousin, J.-M., Meir, P., Lola da Costa, A. C., Mikkelsen, T. N., Salinas, N., Sun, W., and Wingate, L.: Optimal stomatal behaviour around the world, Nat. Clim. Change, 5, 459-464, https://doi.org/10.1038/nclimate2550, 2015.

Muñoz Sabater, J.: ERA5-Land hourly data from 1981 to present. Copernicus Climate Change Service (C3S) Climate Data Store (CDS), https://cds.climate.copernicus.eu/cdsapp\#!/dataset/reanalysis-era5-land?tab=overview, 2019.

Saxton, K. E. and Rawls, W. J.: Soil water characteristic estimates by texture and organic matter for hydrologic solutions, Soil Science Society of America Journal, 70, 1569-1578, https://doi.org/10.2136/sssaj2005.0117, 2006.

Templ, B., Koch, E., Bolmgren, K., Ungersböck, M., Paul, A., Scheifinger, H., Rutishauser, T., Busto, M., Chmielewski, F.-M., Hájková, L., Hodzić, S., Kaspar, F., Pietragalla, B., Romero-Fresneda, R., Tolvanen, A., Vučetič, V., Zimmermann, K., and Zust, A.: Pan European Phenological database (PEP725): a single point of access for European data, Int. J. Biometeorol., 62, 1109-1113, https://doi.org/10.1007/s00484-018-1512-8, 2018.

Tørseth, K., Aas, W., Breivik, K., Fjæraa, A. M., Fiebig, M., Hjellbrekke, A. G., Lund Myhre, C., Solberg, S., and Yttri, K. E.: Introduction to the European Monitoring and Evaluation Programme (EMEP) and observed atmospheric composition change during 1972 - 2009 , Atmos. Chem. Phys., 12, 5447-5481, https://doi.org/10.5194/acp-12-5447-2012, 2012. 